\title{
Identification and Occurrence Records of Lucilia Sericata Meigen (Diptera, Calliphoridae) In Algeria
}

\author{
Meriem Taleb ${ }^{1}$, Ghania Tail ${ }^{1}$, Fatma Zohra Kara ${ }^{1}$, Brahim Djedouani $^{2}$ and T Moussa ${ }^{2}$ \\ ${ }^{1}$ Department of Organismal and Population Biology, Faculty of Nature and Life Sciences, \\ University of Blida 1, 09000 Blida, Algeria. \\ ${ }^{2}$ Entomology Laboratory, Department of Legal Medicine, \\ National Institute for Criminalistics and Criminology, 16002 Cheraga, Algeria.
}

\begin{abstract}
Lucilia sericata, a common blowfly widely distributed in the world which has a forensic, medical, and veterinary importance. The distribution of this species is unknown in Algeria. Therefore, the objective of this study is to identify L. sericata samples and record their occurrence in different regions of Algeria. Samples and data were collected on human corpses, animal carcasses, and different baits between 2010 and 2015. A total number of 2876 specimens were identified. $\mathrm{L}$. sericata is widely distributed throughout Algeria in all the climatic regions and abundant during the spring and the summer. This study presents the first report on the current situation of the distribution of $\mathrm{L}$. sericata in Algeria. It is hoped that it forms baseline information to further studies.
\end{abstract}

Keywords: Lucilia sericata, Diptera, medical entomology, forensic entomology, Distribution, Algeria

\section{Introduction}

The common green bottle fly, Lucilia sericata (Meigen, 1826) (Diptera, Calliphoridae) plays an important role in forensic, medical and veterinary science. In forensic science, it helps to estimate the time of death or postmortem interval (PMI). In medical science, it is used to treat chronic human wounds. It has been demonstrated that the application of sterile larvae to an infected non-healing wound results in the removal of necrotic tissue (debridement), disinfection, rapid elimination of infecting microorganisms and enhancement of the healing process [1]. In the field of veterinary medicine, Lucilia sericata is the predominant cause of sheep blowfly strike world-wide [2].

To understand flies for forensic investigations and veterinary research, one needs to know where they occur, both locally and country-wide. Knowing their geographic distribution would also assist in developing strategies to control fly strike in sheep-farming areas [3]. It is crucial to correctly identify insects in forensic entomology in order to estimate the PMI. Moreover, by knowing the geographical distribution of necrophagous insects forensic entomologists may prove whether a body has been moved from its original location of death [4].

In Algeria, data regarding the occurrence of sarcophagous insects are not available. Therefore, this study aims to identify L. sericata specimens collected from different zones in Algeria and record their presence.

\section{Material and Methods}

\subsection{Sampling}

Samples and data collected on human corpses, animal carcasses and different baits between 2010 and 2015 were analyzed during this study.

To assure the quality of the entomological evidence, crime scene personnel charged with making the collection in different regions of Algeria are trained by the laboratory of Entomology of the National Institute for Criminalistics and Criminology (NICC), Algeria. The same methods of collection and preservation described by Lord and Burger (1983) [5], Adams and Hall (2003) [6] and Amendt et al. (2006) [7]. Collection kits with an illustrated guide are prepared by the laboratory of Entomology of the NICC and provided to investigators all over the country. Arthropods are collected at the end of the crime scene investigation and if necessary, during the autopsy. Flying insects are captured by the standard aerial sweep net technique. Soil under and around the 
body is also sampled for post feeding maggots and puparia. Indoors, arthropods are searched for under carpets, behind furniture, etc.

\subsection{Preservation}

Captured adult insects are placed in vials and killed later by freezing. Samples of immature stages are collected. Some of these are killed immediately in order to be used for identification, while others are kept alive to be raised to adulthood. Larvae are killed using hot water below boiling point during 3-5 min and transferred to $80 \%$ ethanol for storage.

\subsection{Labeling}

Collected specimens are properly labeled. The collection label contains the following information:

- Geographical location

- Date and hour of collection

- Case number

- Location on the body where removed

\subsection{The laboratory work}

\section{a. Samples identification}

When the samples arrive to the laboratory, they are first photographed, labeled, and identified. Identification is made with stereomicroscopes coupled with video and an imagery acquisition chain using dichotomous keys described by Szpila (2010, 2012) [8] [9] and Velasequez et al. (2010) [10]. Species identification is confirmed at least three times.

\section{b. Specimens rearing}

Immature stages are raised in order to estimate the PMI and confirm species identification. They are reared in boxes containing sand and a bovine meat portion and placed inside an environmental chamber simulating temperature $\left(24^{\circ} \mathrm{C}\right)$ and humidity $(70 \%)$.

\section{Results and Discussion}

A total number of 2876 specimens were identified. The eggs of $L$. sericata are elongated yellowish-white ovals and are about $1 \mathrm{~mm}$ long (Figure 1). They are often deposited in batches. Larvae are smooth, conicalshaped and have a complete peritreme surrounding their posterior spiracles (Figure 2). The larval stage is determined by counting the number of slits in each posterior spiracle; one for the first, two for the second, and three for the third instar (Figure 2b). The pupae are about $8-10 \mathrm{~mm}$ long enclosed in a hardened shell that is usually reddish brown (Figure 3 ). The adults are a metallic green with a bright yellow basicosta and the overall diameter is about 5-10 $\mathrm{mm}$ (Figure 4).

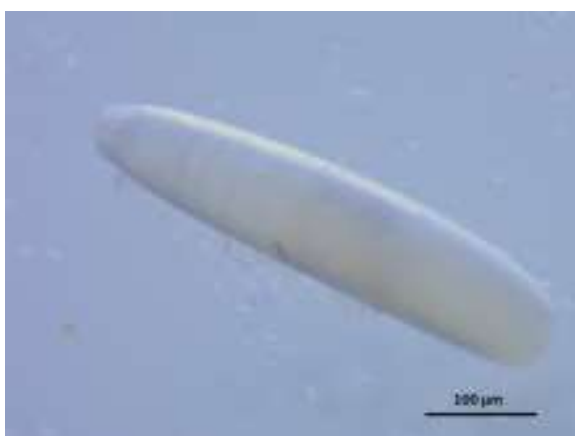

Fig. 1: External egg morphology of Lucilia sericata Meigen (Diptera, Calliphoridae). 


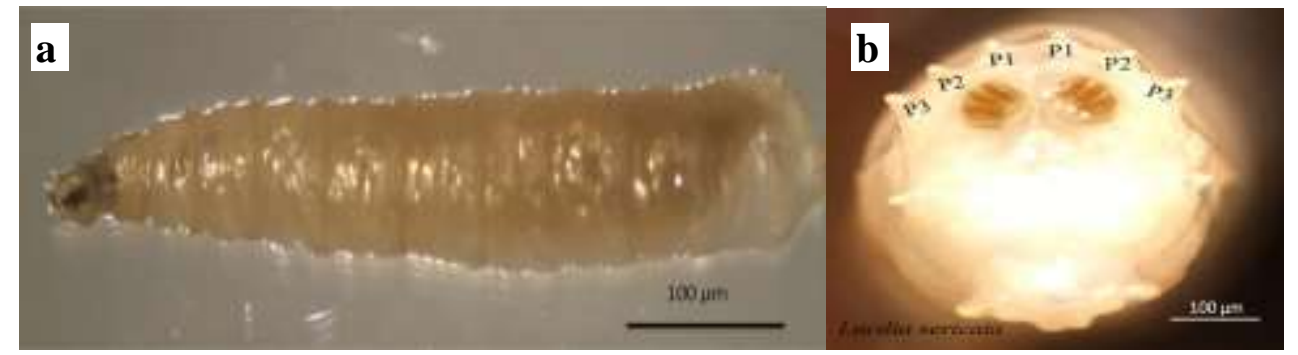

Fig. 2: Third instar-Larva of Lucilia sericata Meigen (Diptera, Callipho :dae). (a) Ventral view. (b) Posterior segment with two spiracles (three slits per spiracle $=$ third instar), distance between each P1 similar to distance between P1 and P2.

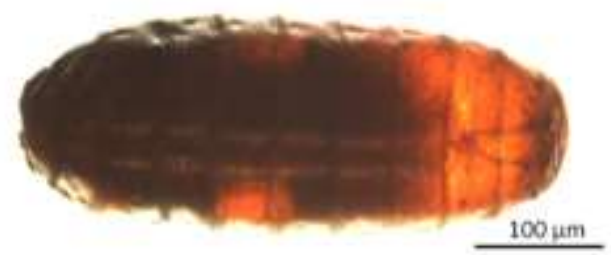

Fig. 3: Dorsal view of Lucilia sericata Meigen (Diptera, Calliphoridae) pupa.

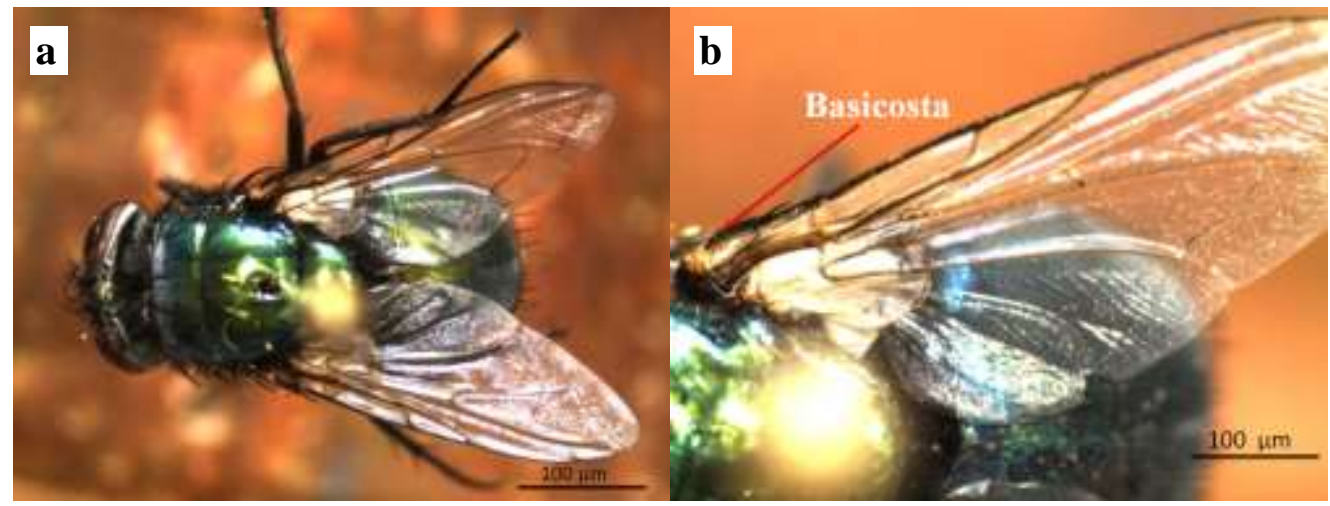

Fig. 4: Adult of Lucilia sericata Meigen (Diptera, Calliphoridae).

(a) Thorax bright green metallic. (b) Basicosta bright yellow.

Occurrence data are depicted in Table 1. In our study, L. sericata was identified from 11 localities (Figure 5). Our results show that L. sericata is widely distributed throughout Algeria in all the climatic regions i.e. humid, sub-humid, arid, semi-arid, and Saharan climate. Regarding seasonal occurrence, our data show that L. sericata is abundant during the spring and the summer.

Lucilia sericata has been described as having a holarctic distribution and is also found in Australia [11], but it could be found anywhere in the world [12].

Valachova et al. (2013) [1] reported that sheep blow fly is coastal in its distribution and prefers warm and moist climates. These observations may explain the occurrence of this species in several coastal regions in Algeria.

Lucilia sericata has been identified among the first colonizers during the warm seasons in Germany [13], in India [14] [15], in Algeria [16] [17] [18] [19] [20] [21], in Portugal [22] [23], in Turkey [24] [25], and in Switzerland [26]. It is a heliotropic species considered in Britain as an indicator species of the sun light [27], which explains its abundance in our study during the spring and the summer. 


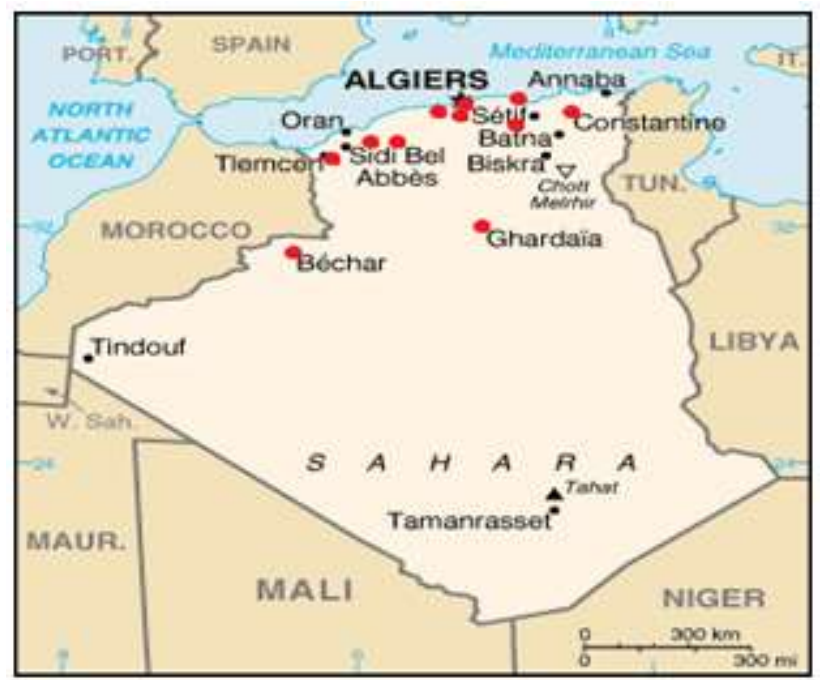

Fig. 5: Distribution map of Lucilia sericata (indicated with red dots) from presence only data in Algeria.

TABLE I: Records of Lucilia sericata occurrence in different climatic regions of Algeria.

\begin{tabular}{lllll}
\hline region & coordinate & season & year & climate \\
\hline Tiaret & $35^{\circ} 22^{\prime} \mathrm{N} / 1^{\circ} 19^{\prime} \mathrm{E}$ & spring & 2015 & semi-arid \\
\hline Bechar & $31^{\circ} 37^{\prime} \mathrm{N} / 2^{\circ} 12^{\prime} \mathrm{W}$ & winter/spring & 2015 & Saharan \\
\hline Bejaia & $36^{\circ} 45^{\prime} \mathrm{N} / 5^{\circ} 3^{\prime} \mathrm{E}$ & spring & 2015 & humid \\
\hline Bejaia & $36^{\circ} 45^{\prime} \mathrm{N} / 5^{\circ} 3^{\prime} \mathrm{E}$ & summer & 2015 & humid \\
\hline Blida & $36^{\circ} 28^{\prime} \mathrm{N} / 2^{\circ} 48^{\prime} \mathrm{E}$ & spring & 2015 & sub-humid \\
\hline Mascara & $35^{\circ} 23^{\prime} \mathrm{N} / 0^{\circ} 8^{\prime} \mathrm{E}$ & spring & 2015 & sub-humid \\
\hline Algiers & $36^{\circ} 46^{\prime} \mathrm{N} / 2^{\circ} 57^{\prime} \mathrm{E}$ & spring & 2015 & humid \\
\hline Algiers & $36^{\circ} 46^{\prime} \mathrm{N} / 2^{\circ} 57^{\prime} \mathrm{E}$ & summer & 2015 & humid \\
\hline Tipaza & $36^{\circ} 34^{\prime} \mathrm{N} / 1^{\circ} 53^{\prime} \mathrm{E}$ & spring & 2015 & humid \\
\hline Blida & $36^{\circ} 28^{\prime} \mathrm{N} / 2^{\circ} 48^{\prime} \mathrm{E}$ & spring & 2014 & sub-humid \\
\hline Ghardaia & $32^{\circ} 29^{\prime} \mathrm{N} 3^{\circ} 40^{\prime} \mathrm{E}$ & spring & 2014 & arid \\
\hline Bordj Bou Arréridj & $36^{\circ} 4^{\prime} \mathrm{N} / 4^{\circ} 45^{\prime} \mathrm{E}$ & summer & 2013 & sub-humid \\
\hline Tlemcen & $34^{\circ} 52^{\prime} \mathrm{N} / 1^{\circ} 19^{\prime} \mathrm{W}$ & spring & 2012 & sub-humid \\
\hline Tipaza & $36^{\circ} 34^{\prime} \mathrm{N} / 1^{\circ} 53^{\prime} \mathrm{E}$ & summer & 2012 & humid \\
\hline Constantine & $36^{\circ} 21^{\prime} \mathrm{N} / 6^{\circ} 36^{\prime} \mathrm{E}$ & spring & 2011 & sub-humid \\
\hline Constantine & $36^{\circ} 21^{\prime} \mathrm{N} / 6^{\circ} 36^{\prime} \mathrm{E}$ & spring & 2010 & sub-humid \\
\hline
\end{tabular}

\section{Conclusion}

The records reported in our study are presence-only data; L. sericata may occur in the other regions or during the other seasons from which samples are not available. This study presents the first report on the current situation of the distribution of L. sericata in Algeria. It is hoped that it forms baseline information to further studies on the spatio-temporal distribution of necrophagous Diptera.

\section{References}

[1] Valachova, J. Bohova, M. Kozanek, P. Takac, and J. Majtan, "Lucilia sericata medicinal maggots: a new source of antimicrobial compounds," in Microbial pathogens and strategies for combating them: science, technology and education, A. Méndez-Vilas, Ed. FORMATEX, 2013, pp. 1745-1753.

[2] J. Kaufmann, Parasitic Infections of Domestic Animals: A Diagnostic Manual, 1996, pp.423. http://dx.doi.org/10.1007/978-3-0348-7666-7 
[3] K.A. Williams, C.S. Richards, and M.H. Villet, "Predicting the geographic distribution of Lucilia sericata and Lucilia cuprina (Diptera: Calliphoridae) in South Africa," African Invertebrates, vol. 55(1), pp. 157-170, June 2014. http://dx.doi.org/10.5733/afin.055.0109

[4] C.H. Wecht and J. T. Rago, Forensic Science and Law: Investigative Applications in Criminal, Civil and Family Justice, 2005, pp. 728.

[5] W.D. Lord and J.F. Burger, "Collection and preservation of forensically important entomological materials," Journal of Forensic Science, Vol. 28, pp.936-944, 1983. http://dx.doi.org/10.1520/JFS11602J

[6] Z.J.O. Adams and M.J.R. Hall, "Methods used for the killing and preservation of blowfly larvae, and their effect on post-mortem larval length,” Forensic Science International, vol. 138, pp. 50-61, August 2003. http://dx.doi.org/10.1016/j.forsciint.2003.08.010

[7] J. Amendt, C.P. Campobasso, E. Gaudry, C. Reiter, H.N. LeBlanc, and M.J.R. Hall, "Best practice in forensic entomology-standards and guidelines," International Journal of Legal Medicine, vol. 121, pp. 90-104, 2006. http://dx.doi.org/10.1007/s00414-006-0086-x

[8] K. Szpila, "Key for the Identification of Third Instars of European Blowflies (Diptera: Calliphoridae) of Forensic Importance," in Current Concepts in Forensic Entomology, J. Amendt, C.P. Campobasso, M.L. Goff, and M. Grassberger , Ed. Springer, London, 2010, pp. 43-56.

[9] K. Szpila, "Key for identification of European and Mediterranean blowflies (Diptera, Calliphoridae) of medical and veterinary importance - adult flies," in Forensic entomology, an introduction, D. Gennard, Ed. Willey-Blackwell, 2012, pp. 77-81.

[10] Y. Velasquez, C. Magana, A. Martinez - Sanc hez, and S. Rojo, "Diptera of forensic importance in the Iberian Peninsula: larval identification key," Medical and Veterinary Entomology, vol. 24(9), pp. 293-308, 2010.

[11] K.G. SMITH, A Manual of forensic entomology. Department of Entomology British Museum (Natural History) and Cornell University Press, London, 1986, pp. 205.

[12] L.C. Rueda, L.G. Ortega, N.A. Segura, V.M. Acero, and F. Bello, "Lucilia sericata strain from Colombia: Experimental colonization, life tables and evaluation of two artificial diets of the blowfly Lucilia sericata (Meigen) (Diptera: Calliphoridae), Bogota, Colombia strain,” Biological Research, vol. 43, pp. 197-203, 2010. http://dx.doi.org/10.4067/S0716-97602010000200008

[13] H. Schroeder, H. Klotzbach, and K. Puschel, "Insects' colonization of human corpses in warm and cold season," Legal Medicine (Tokyo, Japan), vol. 5, pp. 372-374, 2003. http://dx.doi.org/10.1016/S1344-6223(02)00135-9

[14] M. Bharti and D. Singh, "Insect faunal succession on decaying rabbit carcasses in Punjab, India," Journal of Forensic Science, vol. 48, pp. 1133-1143, 2003. http://dx.doi.org/10.1520/JFS2001358

[15] T.V. Sathe, A. Sathe, N.T. Sathe, "Diversity of dipterous forensic insects from Western maharashtra, India," International Journal of Pharma and Bio Sciences, vol. 4(2), pp. 173-179, 2013.

[16] F. Filali, "Contribution a l'étude de la colonisation préférentielle d'un cadavre animal par les insectes nécrophages," M.S. thesis, Université Mentouri Constantine, 2011.

[17] K. Hamel, "Contribution à L'étude de l'influence de la température sur le développement des insectes nécrophages". M.S. thesis . Université Mentouri Constantine, 2011.

[18] M. Taleb, B. Djedouani, M. Moussa, and G. Tail, "Etude de la colonisation d'un cadavre animal par les Diptères nécrophages," presented at the XVIIth National Symposium of Parasitology and Mycology, May $9^{\text {th }}$, 2013, Algiers, Algeria.

[19] M. Taleb, B. Djedouani, M. Moussa, and G. Tail, “Inventaire préliminaire de l'entomofaune cadavérique de la région d'Alger", presented at the 8th international French Conference of Entomology June 23-27, 2014, Hammamet, Tunisia.

[20] M. Taleb, G. Tail, D. Berrabah, M. Saifi, F. Berrouane, and S. Doumandji, "Identification of necrophagous Diptera visiting bait traps in Ghardaia, Algeria," Presented at the the 21st Benelux Congress of Zoology, December 12-13, 2014, Liège, Belgium.

[21] M. Taleb, B. Djedouani, M. Moussa, and G. Tail, "Identification et variation saisonnière des larves de diptères nécrophages dans la région d'Alger," presented at the National Seminar on Faunistic Biodiversity, December 07-09, 2014, Algiers, Algeria.

[22] C.B. Pradro e Castro, "Seasonal carrion Diptera and Coleoptera communities from Lisbon (Portugal) and the utility of forensic entomology in legal medicine," PhD. Dissertation, Universidade de Lisboa, Lisbonne, Portugal, 2011.

[23] C.B. Pradro e Castro, A. Serrano, P. Martins Da Silva, and M.D. García, "Carrion flies of forensic interest: a study of seasonal community composition and succession in Lisbon, Portugal," Medical and Veterinary Entomology, vol. 26(4), pp. 417-31, 2012.

http://dx.doi.org/10.1111/j.1365-2915.2012.01031.x 
[24] E. Çoban, “Edirne ili Trakya üniversitesi Güllapoğlu yerleşkesi’nde adli entomoloji yönünden önem taşiyan diptera faunasinin leş üzerinden toplanmasi ve taksonomik yönden incelenmesi,” M.S. thesis, Trakya Üniversitesi, Trakya, Turkey, 2009.

[25] A. Açikgöz, "Insan cesetleri üzerinden toplanan entomolojik delillerle ölüm zamani tayini," PhD. dissertation, Ankara Üniversitesi, Ankara, Turkey, 2008.

[26] C. Wyss, D. Cherix, Traité d'Entomologie Forensique: Les insectes sur la scène de crime, Presses Polytechniques et Universitaires romandes, Lausanne, 2013, pp. 317.

[27] D. Gennard, Forensic entomology: An introduction, Ltd John Wiley \& Son, London, 2012, pp. 248. 